\title{
Measuring the Effect of A Flipped Classroom Model on Critical Thinking Skills
}

\author{
R Asmara ${ }^{1}$, W R Kusumaningrum ${ }^{2}$, A Wulansari ${ }^{3}$, Munirah ${ }^{4}$, Hersulastuti ${ }^{5}$ \\ 1,2,3 Universitas Tidar, Magelang, Indonesia \\ ${ }^{4}$ Universitas Muhammadiyah Makassar, Makassar, Indonesia \\ ${ }^{5}$ Universitas Widya Dharma Klaten, Klaten, Indonesia \\ 1asmara@untidar.ac.id, 2kusumaningrum@untidar.ac.id, \\ 3atsani_wulansari@untidar.ac.id, 4munirah@unismuh.ac.id, 5hersulastuti@gmail.com
}

\begin{abstract}
The present study investigated the effect of flipped classroom on learners' critical thinking skills of inference and explanation - the flipped classroom used lecturing video as homework and group discussion as classroom activities. The participants were 60 participants aged 19-20 years old. Using quasi-experimental research, this study measured the effect size with the dependent analysis of variance (ANOVA) from the pretest-posttest score on critical thinking skills. Through 10-week intensive meetings, the two groups were identified as intact and control groups and asked to do the procedure starting from the pretest to posttest. The study was able to confirm the effect of the flipped classroom for sharpening students' critical thinking. The intervention for the EFCG was effective to help them to explore their thoughts and develop their critical thinking.
\end{abstract}

Keywords: Flipped Classroom; Digital Natives; Perceptions

\section{INTRODUCTION}

Living in a digital era, the accessible technology has directed the new path of education research. More and more research has been done to investigate the integration technology with language teaching in the classroom. It has urged the traditional pedagogic supporters to shift their teaching styles to be more active, flexible, effective, and student-centred [1] and let the students be independent and responsible learners [2],[3].

In this sense, it supports the integration of a flipped classroom. Acknowledging the popularity in 2012, the notion of a flipped classroom is not a new teaching method. It has modified and adapted the 1990's teaching method of the inverted classroom [4],[5]. It was popularized by two teachers at the Colorado high school namely teachers Jonathan Bergmann and Aaron Sams who created teachernarrated videos for the students to watch at home before school started. The flipped classroom model is based on the idea that traditional teaching is inverted in the sense that what is typically done in 
class is flipped or switched with that which is normally done by the students out of class. In this sense, it offers a more flexible and effective shift and upholds the student-centred learning.

Some studies have been done on the implementation of flipped classrooms [6],[7]. Prasetyo, et al. (2018) did a study on the effectiveness of the flipped classroom learning model in the secondary physics classroom setting [6]. The study was involving the students at the international secondary high school in Indonesia. Using a quasi-experimental research design, the study compared the pretest-posttest scores. The findings revealed that the flipped classroom built the classroom atmospheres better than the traditional teaching method. Sakdiyah, et al. (2018) conducted a study measuring the effectiveness of flipped classroom in enhancing the learners' score [7]. Using experimental research design, the study recommended the implementation of the flipped classroom as an alternative instructional strategy.

The integration of flipped classroom contributes not only to dismantle the traditional learning but also to help the learners to sharpen learners' critical thinking. The other studies have investigated the integration of the flipped classroom in the L2 language teaching to develop learners' critical thinking [8],[9]. DeRuisseau (2016) designed an experimental study investigating the effects of flipped classroom on the participants' critical thinking [8]. This study involved two groups of participants comprising a group of 80 as the experimental group and a group of 50 as the control group at a small liberal arts college in New York, USA. Using ANOVA data analysis, the results suggested that the group with flipped classroom model did a better performance than in the traditional lecture group. Alike with DeRuisseau (2016), Alsowat (2016) did an experimental study to measure the effect of the flipped classroom on learners' higher order thinking skills (HOTS), engagement, and satisfaction [9]. The participants involved 67 female graduate students studying English course at a University in the Kingdom of Saudi Arabia comprising 33 students as the experimental group and 34 as the control group. The statistical data of the study suggested that there were significant differences between the two groups in all of the investigated variables such as students' HOTS, engagement, and satisfaction.

Based on this context, the present study addresses a research question, "Does the flipped classroom model have a greater effect on the Indonesian EFL learners' critical thinking skill development than a traditional instruction model?"

\section{METHOD}

To answer the research questions above on the effect of flipped classroom paradigm to foster students' critical thinking skills, this study adopted quasi-experimental research with non-equivalent group design (NEGD) with pretest-posttest design as its methodological approach. NEGD included a manipulated condition to see the influence of flipped classroom paradigm despite the randomized participants. In this study, we involved two classrooms with relatively similar cognitive and knowledge level as the intact groups and assigned the group 1 as the experimental flipped classroom group (EFCG) and the group 2 as the control non-flipped classroom group (CNFCG). Both groups were given posttest to evaluate their critical thinking skills on interpretation, analysis, inferences, evaluation, explanation, and self-regulation deduction, and overall reasoning skills [10]. For this study, we focus on two factors of inferences and explanation.

This study took the data from two intact groups $(\mathrm{N}=60)$ within the age range of 19-21 years old. The participants were both male and female university students at a state university in Central Java, Indonesia. All of them were Indonesian with Indonesia/Javanese as their L1 and have been learning English at the Department of English for one year. The logic rationale for the selection 
process was (1) among of four classes, the students of the two classes had the equal cognitive and knowledge level, (2) they were born as millennial generation, which implied that they were easy to adopt the technology integration in the classroom.

Using a quasi-experimental approach with non-equivalent group design (NEGD) with pretestposttest design, this research has two main stages including, intervention and post-test model. The present study was carried out in September - November 2018.

The intervention process was initiated by selecting two classrooms with comparable cognitive level and allotting classroom 1 as the experimental flipped classroom group (EFCG) and the classroom 2 as the control non-flipped classroom group (CNFCG). The students in EFCG were attributed to the flipped classroom paradigm. The students were assigned to construct their comprehension towards the topic being discussed by observing from the required videos and supplementary videos at home. To engage the students in the content of the videos, they were guided with weekly learning log. In class, they were assigned to deliver their argumentation about the topic, discuss their interpretation, and clarify their understanding. Furthermore, the researchers measured the critical thinking skills of the two critical thinking skills, i.e., inferences and explanation. The learning log was such an essay test, which was scored 0-5 for each item.

To see the effect of the flipped classroom, we measured the effect size with the dependent analysis of variance (ANOVA) from the pretest-posttest score. The pretest and posttest were testing the participants' critical thinking skills focusing on the inferences and explanation. They were asked to do a typical essay test on some chapter topics. The use of this type allowed us to see the distribution of the two groups, understand the effect of flipped classroom on the two critical thinking skills of inferences and explanation.

\section{RESULT AND DISCUSSION}

The technique of data analysis occupied was both descriptive statistics and parametric inferential statistics. The descriptive statistics was to ensure the equality level of both intact and control groups and to see the normality of the data. The average scores of pretest and posttest from both groups were compared and analyzed by considering the skewness and kurtosis values to the tables. After the normality was statistically identified, this study ran the parametric inferential statistics to see the effect of flipped classroom on the two critical thinking skills, particularly on the inferences and explanation by measuring the dependent analysis of variance (ANOVA).

Before measuring the effect size with the dependent analysis of variance (ANOVA), we investigated the group distribution from the pretest and posttest scores EFCG and CNFCG using the descriptive statistics, as follows.

Table 1 showed the descriptive statistics for examining the normal distribution of the data. Both EFCG and CNFCG were equal with the mean scores for the pretest 68.87 and 68.40 , respectively. The normal distribution was investigated by using skewness and kurtosis values. The data from all phases or steps from pretest, posttest 1 , and posttest 2 were statistically analyzed. From the skewness range of $0.02-0.69$, the skewness value (Zskew) could be drawn into 0.81, 0.92, 0.30 for the EFCG and $0.11,0.31$, and 0.88 for the CNFCG respectively. The Zskew indicated the normal distribution, unskewed. While kurtosis was done for understanding the density of the score distribution. The kurtosis ranges between the range of $0.10-0.82$ with kurtosis value (Zkurt) 0.02 , $0.09,0.27$ for EFCG and 0.52, 0.06, 0.77 for CNFCG. The kurtosis value (below 3) caused the 
histogram shape slightly flat on top and had platykurtic shape. However, the raw data were considered to be normal.

Table 1. Descriptive statistics for the students' performance

\begin{tabular}{|c|c|c|c|c|c|c|c|c|c|c|}
\hline Group & Test & $\mathbf{N}$ & Min & $\begin{array}{c}\text { Ma } \\
\mathbf{x}\end{array}$ & $\begin{array}{c}\text { Mea } \\
\text { n }\end{array}$ & SD & $\begin{array}{c}\text { Skewnes } \\
\text { s }\end{array}$ & $\begin{array}{c}\text { Zske } \\
\text { w }\end{array}$ & $\begin{array}{c}\text { Kurtosi } \\
\text { s }\end{array}$ & $\underset{\mathbf{t}}{\mathrm{Zkur}}$ \\
\hline \multirow[t]{3}{*}{ EFCG } & Pretest & $\begin{array}{l}3 \\
0\end{array}$ & 61 & 80 & 68.87 & $\begin{array}{c}5.1 \\
6\end{array}$ & 0.02 & 0.81 & 0.73 & 0.02 \\
\hline & Posttest 1 & $\begin{array}{l}3 \\
0\end{array}$ & 63 & 82 & 71.13 & $\begin{array}{c}4.8 \\
5 \\
\end{array}$ & 0.08 & 0.92 & 0.82 & 0.09 \\
\hline & Posttest 2 & $\begin{array}{l}3 \\
0\end{array}$ & 65 & 83 & 73.67 & $\begin{array}{c}4.0 \\
2\end{array}$ & 0.24 & 0.30 & 0.27 & 0.27 \\
\hline \multirow[t]{3}{*}{$\begin{array}{c}\text { CNFC } \\
\text { G }\end{array}$} & Pretest & $\begin{array}{l}3 \\
0\end{array}$ & 60 & 76 & 68.40 & $\begin{array}{c}3.5 \\
7\end{array}$ & 0.47 & 0.11 & 0.10 & 0.52 \\
\hline & Posttest 1 & $\begin{array}{l}3 \\
0\end{array}$ & 62 & 77 & 69.07 & $\begin{array}{c}3.3 \\
5\end{array}$ & 0.05 & 0.31 & 0.27 & 0.06 \\
\hline & Posttest 2 & $\begin{array}{l}3 \\
0\end{array}$ & 64 & 78 & 69.40 & $\begin{array}{c}3.3 \\
3\end{array}$ & 0.69 & 0.88 & 0.78 & 0.77 \\
\hline
\end{tabular}

This study measured the effect size with the dependent analysis of variance (ANOVA) to see the distribution of the two groups, understand the effect of flipped classroom on the two critical thinking skills of inferences and explanation.

Table 2. Summary of Analysis of Variance (ANOVA) for EFCG

\begin{tabular}{ccccccc}
\hline Sources & $\boldsymbol{S S}$ & $\boldsymbol{d} \boldsymbol{f}$ & $\boldsymbol{M S}$ & $\boldsymbol{F}$ & $\boldsymbol{P}$ value & $\boldsymbol{F}$ crit \\
\hline Between Groups & 345.96 & 2 & 172.98 & 7.82 & 0.00 & 3.10 \\
\hline Within Groups & 1925.60 & 87 & 22.13 & & & \\
\hline Total & 2271.56 & 89 & 25.52 & & & \\
\hline
\end{tabular}

Table 2 presented that the F-value was 7.82 doubled the F-crit with $3.10(\alpha=0.05)$ and P-value (0.00) was less than the $\alpha(0.05)$. It confirmed that the flipped classroom model had a powerful impact on the two critical thinking skills of inferences and explanation.

Table 3. Summary of Analysis of Variance (ANOVA) for CNFCG

\begin{tabular}{ccccccc}
\hline Sources & $\boldsymbol{S S}$ & $\boldsymbol{d} \boldsymbol{f}$ & $\boldsymbol{M S}$ & $\boldsymbol{F}$ & $\boldsymbol{P}$ value & $\boldsymbol{F}$ crit \\
\hline Between Groups & 15.56 & 2 & 7.78 & 0.67 & 0.52 & 3.10 \\
\hline Within Groups & 1016.27 & 87 & 11.68 & & & \\
\hline Total & 1031.82 & 89 & 11.59 & & & \\
\hline
\end{tabular}

Table 3 indicated the ANOVA results for CNFCG for the traditional classroom teaching method. As shown from the table, the F-value was 0.67 less than the F-crit 3.10 with $(\alpha=0.05)$ and P-value (0.52) higher than the $\alpha(0.05)$. It confirmed that the traditional method was not significant to elicit participants' critical thinking skills. 
To understand the effect of flipped classroom on critical thinking skills of inferences and explanation, we involved questions in isolation rather than in non-isolated condition. During the treatment given, the participants for EFCG were assigned to construct their comprehension towards the topic being discussed by observing the required videos and supplementary videos at home using the printable observation sheet. Based on the concept, the issue of explanation and inferences was depicted, as follow.

Table 4. Summary of critical thinking skills

\begin{tabular}{cccc}
\hline Category & Task & \multicolumn{2}{c}{$\begin{array}{c}\text { The pretest-posttest average score } \\
\text { changes }\end{array}$} \\
\cline { 3 - 4 } & & EFCG & CNFCG \\
\hline Inferences & $\begin{array}{c}\text { Synthesizing and making } \\
\text { a conclusion }\end{array}$ & 2.64 & 0.55 \\
\hline explanation & Presenting the arguments & 2.16 & 0.45 \\
\hline
\end{tabular}

The table 4 clearly showed that flipped classroom facilitated the EFCG participants' critical thinking for inference skill from 37.88 to 40.52 for the EFCG and the CNFCG from 37.62 to 38.17 , while for the explanation skill for the EFCG from 30.99 to 33.15 and the CNFCG from 30.78 to 31.23. Based on this direct comparison of the average scores of both groups, the EFCG outperformed the CNFCG in both critical thinking skills. We might infer that the principles and the process of flipped classroom assisted the EFCG participants to explore their mind and thoughts as the initial phase for sharpening their critical thinking to be better. Otherwise, the traditional method, which was implemented in the CNFCG classroom and characterized by listening to the teacher explanation, did not give a big contribution to their critical thinking skills development. The students tended to be passive and only be feed with information about certain topics. It might cause their learning to be loaded with absorbing information and memorization.

\section{CONCLUSION}

This present study measured the effect of a flipped classroom model on the participants' critical thinking skills comprising explanation and inference. Through 10 -week intensive meetings, the two groups were identified as intact and control groups and asked to do the procedure starting from the pretest to posttest. As it has been seen, the intact group or the primarily acknowledged as the EFCG outperformed the CNFCG, though they have an initial cognitive level. Therefore, the study was able to verify the effect of the flipped classroom for sharpening students' critical thinking. The intervention for the EFCG was effective to help them to explore their thoughts and develop their critical thinking.

\section{REFERENCES}


[1] J. Nouri, "The flipped classroom: for active, effective and increased learning - especially for low achievers," Int. J. Educ. Technol. High. Educ., vol. 13, no. 1, p. 33, Dec. 2016.

[2] M. B. Gilboy, S. Heinerichs, and G. Pazzaglia, "Enhancing Student Engagement Using the Flipped Classroom," J. Nutr. Educ. Behav., vol. 47, no. 1, pp. 109-114, Jan. 2015.

[3] V. Betihavas, H. Bridgman, R. Kornhaber, and M. Cross, "The evidence for 'flipping out': A systematic review of the flipped classroom in nursing education," Nurse Educ. Today, vol. 38, pp. 15-21, Mar. 2016.

[4] M. Correa, "Flipping the Foreign Language Classroom and Critical Pedagogies," High. Educ. Futur., vol. 2, no. 2, pp. 114-125, Jul. 2015.

[5] N. Kang, "The comparison between regular and flipped classrooms for EFL Korean adult learners," Multimedia-Assisted Lang. Learn., vol. 18, no. 3, pp. 41-72, 2015.

[6] B. D. Prasetyo, N. Suprapto, and R. N. Pudyastomo, "The effectiveness of flipped classroom learning model in secondary physics classroom setting," J. Phys. Conf. Ser., vol. 997, no. 1, p. 12037 , Mar. 2018.

[7] H. Syakdiyah, B. Wibawa, and H. Muchtar, "The effectiveness of flipped classroom in high school Chemistry Education,” IOP Conf. Ser. Mater. Sci. Eng., vol. 434, no. 1, p. 12098, Dec. 2018.

[8] F.-J. Lin, J. Samp, A. Munoz, P. S. Wong, and A. S. Pickard, "Evaluating change using patient-reported outcome measures in knee replacement: the complementary nature of the EQ-5D index and VAS scores," Eur. J. Heal. Econ., vol. 15, no. 5, pp. 489-496, Jun. 2014.

[9] H. Alsowat, "An EFL flipped classroom teaching model: Effects on English language higher-order thinking skills, student engagement and satisfaction," J. Educ. Pract., vol. 7, no. 9, pp. 108-121, 2016.

[10] P. A. Facione, "Critical Thinking: What It Is and Why It Counts," Insight Assess., pp. 128, 2013. 